\title{
Comparative Assessment of Growth Performance and Nutrients Utilization of African Catfish (Clarias gariepinus, Burchell 1882) Fed Chicken Offal and Shrimp-Based Diets
}

\author{
Elvis Monfung Ayim ${ }^{1}$, Ettah Akpang Ivon ${ }^{2}$, Raymond Odey Ajang ${ }^{1}$ \\ and Akaninyene Paul Joseph ${ }^{1^{*}}$ \\ ${ }^{1}$ Department of Zoology and Environmental Biology, Faculty of Biological Sciences, University of \\ Calabar, Calabar, Nigeria. \\ ${ }^{2}$ Department of Science Laboratory Techniques, Faculty of Biological Sciences, University of Calabar, \\ Calabar, Nigeria. \\ Authors' contributions \\ This work was carried out in collaboration among all authors. Author APJ designed the study, \\ performed the statistical analysis, wrote the protocol, and wrote the first draft of the manuscript. \\ Authors EMA and EAI managed the analyses of the study. Author ROA managed the literature \\ searches. All authors read and approved the final manuscript. \\ Article Information \\ DOI: $10.9734 / A R R B / 2018 / v 30 i 530026$ \\ Editor(s): \\ (1) Dr. Eugene A. Silow, Institute of Biology, Chair of invertebrate Zoology and Aquatic Ecology Sukhe-Baator str., Russia. \\ (2) Dr. George Perry, Dean and Professor of Biology, University of Texas at San Antonio, USA. \\ (1) Mohamed EL. Sayed Megahed, National Institute of Oceanography and Fisheries, Egypt. \\ (2) Magdy Mohamed Aly Gaber Aquaculture, National Institute of Oceanography and fisheries, Egypt. \\ (3) Dr. Lucky Uche Onyia, University of Technology Yola, Nigeria. \\ Complete Peer review History: http://www.sdiarticle3.com/review-history/43149
}

Original Research Article

Received 03 June 2018

Accepted 14 August 2018

Published 14 March 2019

\section{ABSTRACT}

A comparative study on the growth performance of African catfish (Clarias gariepinus) fed shrimp based diet (SBD), chicken offal based diet (COBD) and coppens feed was carried-out for 22 weeks in concrete tanks measuring $3.5 \times 1.7 \times 1.5 \mathrm{~m}^{3}$. Triplicate groups of 40 juveniles with average length of $9.15 \pm 0.17 \mathrm{~cm}$ and weight of $20.00 \pm 2.58 \mathrm{~g}$ were stored in each tank. A total of 360 juveniles were used throughout the study. Fish were fed daily at $3 \%$ of their body weight through-out the duration of the experiment. The nutrient composition of the 3 nutrients differed significantly at $p<0.05$. Weight gain (WG) $(\mathrm{g})$ was highest $(17189.33 \pm 506.61 \mathrm{~g})$ in fish fed diet A (Coppens feed), followed by $15045.33 \pm 202.42 \mathrm{~g}$ (diet B) (SBD) and least $(14357.33 \pm 108.25 \mathrm{~g})$ (diet C) (COBD). The Growth 
rate (GR) was highest in fish fed with diet A (111.62 $\pm 3.29 \mathrm{~g} /$ day), followed by $97.69 \pm 1.31 \mathrm{~g} /$ day (diet B), and least $(93.23 \pm 0.70 \mathrm{~g} /$ day) in diet C. Specific growth rate (SGR) was highest in juveniles fed diet A (2.02 $\pm 0.02 \% /$ day), followed by $1.94 \pm 0.01 \% /$ day for diet B, and least $(1.91 \pm 0.01 \% /$ day $)$ for diet $C$. Mean growth rate (MGR) was highest in juveniles fed diet $A(11.88 \pm 0.29 \mathrm{mg} / \mathrm{day})$, followed by $11.74 \pm 0.15 \mathrm{mg} /$ day for diet $B$, and least $(11.69 \pm 0.09 \mathrm{mg} /$ day $)$ in fish fed diet $C$. The WG, GR and SGR varied significantly between the juvenile fish group fed the 3 diets at $p<0.05$, while MGR did not vary significantly between fish group fed the 3 diets at $p>0.05$. Fish fed diet $A$ had a higher feed consumption (FC) $(41650.00 \pm 315.34 \mathrm{~g} / \mathrm{kg})$, than that fed diet $\mathrm{B}(39034.24 \pm 86.34$ $\mathrm{g} / \mathrm{kg})$ and then diet C (38276.00 $\pm 342.97 \mathrm{~g} / \mathrm{kg})$. Juveniles fed Coppens feed did better, with a feed conversion ratio (FCR) of $2.42 \pm 0.06$, followed by $2.59 \pm 0.04$ for diet $B$ and $2.67 \pm 0.03$ for fish fed diet C. Feed conversion efficiency (FCE) was higher in fish fed diet A (41.26 $\pm 0.94 \%)$, followed by $38.54 \pm 0.54 \%$ (diet B) and least $(37.52 \pm 0.51 \%)$ (diet C). The FC and FCR varied significantly between the fish fed the 3 diets at $p<0.05$, while FCE was not significantly different between the 3 treatment groups at $p>0.05$. The water parameters of the culture water varied significantly between each treatment groups $(p<0.05)$, and were within the rage suitable for normal growth of fish. Though coppens feed yielded better growth performance and feed utilisation, the use of COBD and SBD is recommended for fish farmers in Nigeria. More researches should be carried out on using chicken offals and shrimps in fish feed formulation.

Keywords: Growth performance; feed utilization; feed composition; Clarias gariepinus; coppens; chickel offal and shrimp based diet.

\section{INTRODUCTION}

Clarias gariepinus has been widely regarded as one of the most relevant tropical fresh water species of fish for aquaculture, because of the potentials they exhibit as documented by [1]. Nutritionally, this fish is rich in vitamin $D$, low in Omega-3 fatty acids and high in Omega-6 fatty acids, which promote growth and brain development. It has a fast growth performance rate based on tolerance of adverse ecological condition. The primary objectives of the aquaculture industry are to optimize growth and make available high-quality fish [2], and with an increase in the World-wide awareness of fish as a treasured source of protein, has led to an increase in the prospects of aqua feeds with diets being specially design to meet the nutritional needs of species, life cycle and the health conditions of fish [3]. Fishmeal has been the most used source of protein incorporated in culture fish diets, despite the fact that, fish supply is not increasing globally [4]. The prerequisite for the development of large-scale aquaculture is discovering locally formulated feeds of highquality protein to replace fish meal. Many fish nutritionist have studied alternative sources of fish protein, both from plant and animal with some successes $[5,6,7,8]$, some of which include earthworm and termite (Macrotermes Subhyalinus) meals [9], Maggot meal $[10,11]$ and Phane (Imbrasia belina), insect [12] to replace fishmeal that is desired as the chief source of protein in diets of fish, primarily due to its high digestibility and rich essential amino acids (EAAS). Essential amino acids cannot be synthesized in required quantities necessary for fish growth and tissue development, hence, must be fortified in diets of fish [13]. Re-cycled chicken meal is termed as the dry rendered product from an aggregate of chicken flesh, skin and bone obtained from whole carcass of chicken with the exception of feathers, which are ground and reduced in particle size [14]. Aquaculture possesses the capacity to become a sustained farming practice which can add to captured fisheries, and considerably help in feeding the growing population of the World [15]. In the year 2002 , about $70 \%$ of global production of reared fish was recorded to have been in China alone [16]. Udo et al. [17] concurred that for the ingredients to be introduced into least-cost ration, there is need for the evaluation of nutrients, as it exposes several key aspects for different experimental methods used. Many researchers [18] and [19] stated that knowledge of the ingredients to be used in the formulation of feed for the African catfish is essential, particularly about ingredient digestibility, specification, palatability. Many researchers [20] and [21] purported that, the nutritional constituents of chicken offal meal can vary depending on the part being processed. Fish feed remain one of the major input in fish production. In Nigeria, the major challenge confronting the development and growth of aquaculture is lack of feed, the technology of fish feed production is little developed in Africa and some developing 
Countries [22]. The study was aimed at assessing the growth performance of African Catfish (C. gariepinus) juveniles fed with chicken offal and shrimp-based diets.

\section{MATERIALS AND METHODS}

\subsection{Study Area}

This research took place at Andem and Sons Fish Farm Limited, located in Calabar South Local Government Area, Calabar, Cross River State, Nigeria.

\subsection{Experimental Design}

This research work was undertaken for 22 weeks (i:e five months and two weeks); between JuneNovember, 2016. Nine concrete tanks measuring $\left(3.5 \times 1.7 \times 1.5 \mathrm{~m}^{3}\right)$ were used. The 9 concrete tanks were used, labelled $A_{1}, A_{2}, A_{3}, B_{1}, B_{2}, B_{3}$ and $\mathrm{C}_{1}, \mathrm{C}_{2}, \mathrm{C}_{3}$, making 9 experimental units to aid replication of the experiment. Two different types of experimental fish diet were formulated with the addition of Chicken offal (diet C), shrimp waste (diet $B$ ), which were used to compare with Coppens commercial feed (control) (diet A). This scientific study was conducted in replicates of 3 , using fish juveniles with the average length of $9.15 \pm 0.17 \mathrm{~cm}$ and average weight of $20.00 \pm 2.58 \mathrm{~g}$. The experimental fishes were fed twice a day between 7:00 and 8:00am and 6:00 and $7: 00 \mathrm{pm}$ at $3 \%$ of their body weight.

\subsection{Collection, Preservation and Preparation of Chicken Offals and Shrimp Waste}

The chicken offal used in this study was purchased from the Watt Market and Mr. Runyi broiler slaughtering farm at the Cross River State Water Board premises, all in Calabar, Cross River State.

The freshly collected offal was thoroughly washed in water carefully to remove the faecal content as much as possible before weighing. The Chicken offal was then par boiled for 30 minutes. It was allowed to cool and then sun dried. Shrimp waste was obtained at the Calabar beach market in the dry form, it was then packed in a sack bag and kept in a dry place until when needed.

\subsection{Diets Ingredient and Diet Formulation Methods}

Experimental diet were composed of Soyabean meal (SBM), Chicken offal (CO), Shrimp meal (SHM), Wheat offal (WO), Cassava starch, vitamin premix, bone ash/calcium, Sodium chloride $(\mathrm{NaCl})$, vegetable oil, lysine, methionine.

Two diets were formulated for this experiment, adopting Pearson square system to arrive at a crude level of protein of $42 \%$. Various ingredients of feed were grinded and amalgamated properly in accordance with their percentages. After which the feed were pelletised using a Hand Cranker machine into small sizes and oven dried. Soon after drying was over, the feed were packed in bags and stored. The processes of the feed formulation were all carried out at Aqua Marvels Farms in Calabar. The farm is also a designated centre ( Nigeria Markets II) used by the United State Agency for International Development (USAID) for Wet Field Demonstration on improved Aquacultural Practices, which was established in 2014. The components and proportions of ingredients making-up the diets were:

\begin{tabular}{lllll}
\hline Ingredients & \multicolumn{2}{c}{ Diet B } & \multicolumn{2}{c}{ Diet C } \\
\cline { 2 - 5 } & Amount in g & $\mathbf{( \% )}$ & Amount in g & $\mathbf{( \% )}$ \\
\hline Chicken offal (CO) & -- & --- & 370 & 37 \\
Shrimps meal (SHM) & 360 & 36 & --- & -- \\
Soybeans meal (SBM) & 360 & 36 & 370 & 37 \\
Yellow maize (YM) & 120 & 12 & 110 & 11 \\
Wheat offal (WO) & 120 & 12 & 110 & 11 \\
Methionine & 2.5 & 0.25 & 2.5 & 0.25 \\
Lysine & 2.5 & 0.25 & 2.5 & 0.25 \\
Bone ash/calcium & 5 & 0.5 & 5 & 0.5 \\
Vitamin premix & 15 & 1.25 & 15 & 1.25 \\
Sodium chloride (NaCl) & 5 & 0.5 & 5 & 0.5 \\
Cassava Starch & 5 & 0.5 & 5 & 0.5 \\
Palm oil & 5 & 0.5 & 5 & 0.5 \\
Total in g/kg & $1 \mathrm{~kg}$ & $1 \mathrm{~kg}$ & \\
\hline \multicolumn{4}{c}{ Diet B= Shrimp-based diet (SBD), Diet C = Chicken Offal-based diet (COBD) }
\end{tabular}




\subsection{Coppens Feed Composition and Characteristics}

Coppens feed produced by Coppens International in Netherlands is made up of good standard ingredients like calcium, methionine, copper sulphate (CuSo4), marine fish meal, phosphorus, lysine, selenium refined fish oil and several grains. Sizes of coppens feed used were $3 \mathrm{~mm}, 4 \mathrm{~mm}$ and $6 \mathrm{~mm}$ respectively.

\subsection{Tank Treatment}

Prior to the commencement of the experiment, the tanks were treated with common salt sodium chloride $(\mathrm{NaCl})$ for complete extermination of micro-organisms which can pose a threat to the juveniles. After which water was filled and allowed for two weeks, then flushed out, before the refilling and introduction of the juveniles.

\subsection{Fish stocking and Experimental Procedures}

Borehole water (ground water) was the source of water, was pumped into the tanks by electrical pump and piped into the experimental tanks. Three hundred and sixty (360) juveniles were obtained from the University of Calabar Fish Farm Hatchery complex, Institute of Oceanography, Calabar, and transported to Andem and Sons fish farm in 50 liter water storage tank, where they were allowed to acclimate to the new environmental conditions for about 2 weeks. During this period, they were fed twice a day between 7:00 and 8:00am and $6: 00$ and $7: 00$ pm at $3 \%$ of their body weight. Forty fish juveniles with average length of $9.15 \pm 0.17 \mathrm{~cm}$ and average weight of $20.00 \pm 2.58 \mathrm{~g}$ were stocked per unit. Before stocking, the initial length and weight of each fish sample was accurately measured using a measuring board (to the nearest centimeters) and electronic weighing balance (Metlar mt-5000D version) (to the nearest grams) respectively. The culture water was changed every 48 hours, in order to maintain good water quality through-out the experiment.

The fish were sampled bi-weekly to determine their growth and survival (mean body weight, mean total length and mortality). The rations was always adjusted so as to correspond with the new body weight using the weighing balance. The sampling exercises were carried out between 7-8am to minimize heat stress [23].

\subsection{Monitoring of Water Quality Parameters}

Water quality parameters like; dissolved oxygen (DO), hydrogen ion concentration $(\mathrm{pH})$, temperature $\left({ }^{\circ} \mathrm{C}\right)$, ammonia $\left(\mathrm{NH}_{3}\right)$ were measured bi-weekly, through-out the experiment. Mercury-in-glass thermometer was used for measuring water temperature in degrees celsius. The $\mathrm{pH}$ and oxygen concentrations were measured in-situ using the Jenway meters; model 3050, England for DO in milligram per liter $(\mathrm{mg} / \mathrm{L})$ and model 9070 for $\mathrm{pH}$. Water was collected into a 1 liter container, preserved in an ice chest before taking to the physico-chemical laboratory of the Cross River State Water board, Calabar for ammonia level determination using spectrophotometer in $\mathrm{mg} / \mathrm{L}$.

\subsection{Proximate examination of the Experimental Diets}

The proximate analysis of the formulated diets were determined according to standard methodology of [24]. Crude protein content was determined using Kjeldahi method. All proximate analysis were carried-out in the Faculty of Agriculture Central Laboratory, University of Calabar.

\subsubsection{Determination of moisture level}

A neat crucible was subjected to drying in an oven to a constant weight (a) before introducing a quantity of the sample into a beaker, then weighed (b). Next, the sample was dried inside a ventilated heated oven which was powered electrically at $75^{\circ} \mathrm{C}$ for 24 hours, then allowed to cool in a desiccator, and then weighed. The procedure was repeated until a constant weight (c) was reached. Same procedure was repeated 3 times for each sample. The percentage moisture level was mathematically calculated using the formula:

$\%$ moisture content $=\frac{b-c}{b-a} \times 100 \%$

\subsubsection{Ash content}

The crucible was ignited at $550^{\circ} \mathrm{C}$ for 3 hours, then cooled and weighed. Five grams of the sample was placed in the crucible and weighed. It was then burnt at $550^{\circ} \mathrm{C}$ for a day, cooled and then weighed. Same procedure was carried out over and over again until a constant weight was obtained. The calculation of 
percentage ash content followed the formula as shown below:

$$
\% \text { Ash content }=\frac{\text { wt of ash }}{\text { wt of sample }} \times 100
$$

\subsubsection{Crude fat or ether extract}

Five grams of the sample was weighed and put in a thimble. About $120 \mathrm{~mL}$ of petroleum ether was emptied into an earlier dried and weighed round bottom flask. The thimbles and its content were introduced into an extractor known as the soxhlet extractor, which became fitted into the spherical bottom flask and then condensed together with the extraction apparatus to allow the sitting of the flask on the spaces provided in the hot plate. The hot plate was set to gentle heat. With tap on, the ether evaporated and condensed, dropping into a thimble from where it extracted the soluble ether contents into a round bottom flask. The process continued for 10 hours, the thimble was removed and dried in the air, later the fat from the extract was utilize for the determination of fibre. Then, petroleum ether present in the flask was distilled off and received in the soxhlet extractor tube. Drying of the flask was carried out in an air circulating desiccator for two days. The circular bottom flask with the lipid extract inside was then weighed. The content inside the flask was dried and weighed to a constant weight. The lipid quantity that was obtained from the difference between the flasks weighed previously and later-on was obtained as shown below:

$$
\% \text { Ether Extract }=\frac{w t \text { of extract }}{w t \text { of } \text { sample }} \times 100
$$

\subsubsection{Crude fibre}

For acid digestion, the fat free material (8-10g) was weighed and transferred into a $400 \mathrm{~mL}$ beaker that was previously marked at $200 \mathrm{~mL}$ level. Fifty milliliters of sulphuric acid (i:e 1.25\%) was added and the mixture rose to $200 \mathrm{~mL}$ marked. The beaker together with the content was heated to a boiling point for half an hour. The content of the beaker was then filtered through a Buchner funnel with the aid of a suction pump. The residue was washed with hot water until it was acid free. For base digestion, the residue left after acid digestion was transferred into $400 \mathrm{~mL}$ beaker. The mixture was again heated for 30 minutes with constant stirring. The content of the beaker was filtered through the Buchner funnel and washed several times with hot water until it was free from sodium hydroxide. Finally, the residue was washed twice with $95 \%$ methanol, then quantitatively transferred into a porcelain crucible and dried at $100^{\circ} \mathrm{C}$. The weight of the dry residue was noted, and the residue ignited in a furnace at $550^{\circ} \mathrm{C}$. The weight of the ash left after ignition was also noted. The crude fibre content was determined from the loss in weight of crucible and its content after ignition.

\subsubsection{Crude protein estimation $(6.25 \times \mathrm{N})$ micro kheljahl method}

One grams of the sample powder was measured for weight into $50 \mathrm{~mL}$ digestive Kjeldahl flask. About $20 \mathrm{~mL}$ of concentrated $\mathrm{H}_{2} \mathrm{SO}_{4}, 1$ tablet of Kjeldahl catalyst and a pinch of antibumbing chips were included. Same mixture sample was incinerated into a slowly boiling digestion rock, then subjected to strong heating till the digest appeared clear, before heating for further 3 hours. The digest at this point was removed and allowed to get cold, then certain amount of a known quantity was transferred into $100 \mathrm{~mL}$ volumetric flask up to a required mark. The Erlenmeyer flask with $100 \mathrm{~mL}$ of boric acid solution indicator was placed on the tip of the condenser unit of the distillation apparatus (which had been steam washed), so that the condenser tip is extended below the upper layer of the solution. Then $10 \mathrm{~mL}$ of the digest sample was put into the dums sample tube and made to undergo steam heating. About $10 \mathrm{~mL} \mathrm{NaoH}$ solution at $40 \%$ was included in the digest and steam distilled into the Erlenmeyer flask until the content increased more than double its original quantity. As the ammonia distilled into the boric acid indicator solution, it transformed into green. A black determination was conducted in the same manner as highlighted above, exception that here, the digestion sample was substituted by $0.1 \mathrm{ml}$ of distilled $\mathrm{H}_{2} \mathrm{O}$. The sample inside the Erlenmeyer flask was subjected to titration with $0.1 \mathrm{NH}_{4} \mathrm{Cl}$ to arrive at pink end. Percentage protein was calculated as shown below:

$$
\begin{aligned}
& \% \text { protein }=(\mathrm{MI} \mathrm{HCl}(\text { test })-\mathrm{MI} \mathrm{HCl}(\mathrm{BLANK})) \times \\
& \text { normality of acid } \times \frac{1.4}{1000} \times \frac{100}{10} \times 6.25 \times \frac{100}{0.1}
\end{aligned}
$$

\subsection{Determination of Growth Perfor- mance}

All growth performance parameters were calculated following the method stated by [25] as follows: 


\subsubsection{Weight gain (g)}

This was given as final weight $\left(\mathrm{W}_{2}\right)$ - initial weight $\left(\mathrm{W}_{1}\right)$

\subsubsection{Length gain $(\mathrm{cm})$}

This was given as final length $\left(L_{2}\right)$ - initial length $\left(\mathrm{L}_{1}\right)$

\subsubsection{Growth Rate (GR)}

This was evaluated as final weight $\left(\mathrm{W}_{2}\right)$ - initial weight $\left(W_{1}\right) /$ Number of days

\subsubsection{Specific growth rate (SGR)}

This was evaluated as the percentage of weight gain per day

SGR $=$ Ln weight $\left(W_{2}\right)$ final - Ln weight $\left(W_{1}\right)$ initial/(Number of days) 100 OR written as: $100\left(\mathrm{LnW}_{2}-\mathrm{LnW}_{1}\right) /\left(\mathrm{T}_{2}-\mathrm{T}_{1}\right)$

Where:

$$
\begin{aligned}
& W_{2}=\text { Weight (final) at end of time } T_{2} \\
& W_{1}=\text { Weight (initial) at beginning of time } T_{1} \\
& L n=\text { natural base of logarithm }
\end{aligned}
$$

\subsubsection{Mean growth rate (MGR)}

This was calculated as average weight gain in million grams per day.

$$
\begin{aligned}
& \text { M.G.R }=[1000(W 2-W 1)] /[o .5(W 2+ \\
& W 1) t] \mathrm{mg} / \mathrm{g} \text { day }
\end{aligned}
$$

Where;

$$
\begin{aligned}
& \mathrm{W}_{2}=\text { Final weight }(\mathrm{g}) \\
& \mathrm{W}_{1}=\text { initial weight }(\mathrm{g}) \\
& \mathrm{t} \quad=\text { Duration of experiment in days }
\end{aligned}
$$

\subsubsection{Percentage weight gain (PWG)}

This was calculated as follows;

$P W G=100\left(W_{2}-W_{1}\right) / W_{2}$

Where,

$$
\begin{aligned}
& W_{2}=\text { weight }(\text { final) } \\
& W_{1}=\text { weight (initial) }
\end{aligned}
$$

\subsection{Determination of Food Utilization}

All food utilization parameters were calculated according to the method described by [25].

\subsubsection{Food consumed (g)}

This was given as $5 \% \mathrm{X}$ body weight $X$ No. of days

\subsubsection{Food conversion ratio}

This was stated as: Consumed feed (g)/ Weight gain $(\mathrm{g})$

\subsubsection{Food conversion efficiency}

This was given as: [Weight gain (g)/Feed consumed $(\mathrm{g})]$ X 100

\subsection{Statistical Analysis}

Data obtained were subjected to descriptive analysis (mean and standard deviation). One way analysis of variance (ANOVA) was also used to test for the significance of difference between physico-chemical parameters of water, growth performance and food utilization parameters of each treatments group. One way ANOVA was also used to test for the significance of difference in proximate composition between the 3 treatments diets using Version 20 of predictive Analytical Software (PASW) and Microsoft Excel 2013 at 0.05 level of significance and at their relevant degree of freedom.

\section{RESULTS}

\subsection{Proximate Composition of Experi- mental Diet}

The summary of the mean proximate composition of the experimental diet is shown in Table 1. Mean proximate analysis of the dry matter $(\mathrm{mg} / 100 \mathrm{~g})$ of the three experimental diets showed that crude protein content was highest $(40.61 \pm 0.13 \%)$ in diet A (Coppens), followed by diet $C$ (chicken offal based diet) (COBD) with $38.15 \pm 0.16 \%$ and least $(37.00 \pm 0.32 \%)$ in diet $B$ (shrimp based diet) (SBD). Mean ether extract was highest in diet $A(11.71 \pm 0.10 \%)$, followed by diet $C(10.00 \pm 0.30 \%)$ and least in diet $B$ $(6.70 \pm 0.12 \%)$. Mean crude fibre was also highest in $\operatorname{diet} A(7.43 \pm 0.01 \%)$, followed by diet B $(5.13 \pm 0.13 \%)$, and least in $\operatorname{diet}$ C $(4.30 \pm$ $0.33 \%)$.

Also, mean ash content was maximum in diet $A$ $(9.10 \pm 0.12 \%)$, followed by diet B $(6.67 \pm 0.33$ $\%)$, and least in diet C (5.00 $\pm 0.00 \%)$. Mean moisture content was highest in diet B (17.37 \pm $0.31 \%)$, followed by diet C (14.84 $\pm 0.14 \%)$ and 
least in diet $A(8.50 \pm 0.21 \%)$. Mean nitrogen free extract (NFE) was greater in diet C $(27.76 \pm$ $0.56 \%)$, followed by diet $B(27.13 \pm 0.23 \%)$ and least in diet $\mathrm{A}(22.68 \pm 0.13 \%)$ (Table 1).

From the statistical point of view, nutritional composition varied significantly between the 3 feeds at $p<0.05$.

\subsection{Growth Performance of Fish Fed Experimental Diets}

The summary of the growth performance of fish fed 3 different diets are shown in Table 2. Growth performance of juveniles (C. gariepinus) that were administered the 3 test diets was evaluated using indices including; weight gain (g), growth rate (g/day), specific growth rate (\%/day) and mean growth rate $(\mathrm{mg} /$ day). Weight gain $(\mathrm{g})$ was highest $(17189.33 \pm 506.61 \mathrm{~g})$ in fish fed diet $\mathrm{A}$ (Coppens feed), followed by $15045.33 \pm 202.42 \mathrm{~g}$ for fish fed diet B (shrimp based diet) and least $(14357.33 \pm 108.25 \mathrm{~g})$ in fish fed diet C (chicken offal based diet). The Growth rate (GR) was equally highest in juveniles fed with Coppens feed (111.62 $\pm 3.29 \mathrm{~g} /$ day), followed by $97.69 \pm 1.31 \mathrm{~g} /$ day for fish fed diet $\mathrm{B}$, and least $(93.23 \pm 0.70 \mathrm{~g} /$ day) in fish fed diet C (Table 2).

Specific growth rate (SGR) observed was highest in juveniles fed Coppens feed (2.02 \pm 0.02 $\% /$ day), followed by $1.94 \pm 0.01 \% /$ day for fish fed diet $B$, and least $(1.91 \pm 0.01 \% /$ day $)$ in fish fed diet $C$. Mean growth rate maintained the same line of increase in juveniles fed diet $A$ (Coppens) reflecting highest value (11.88 \pm 0.29 $\mathrm{mg} /$ day), followed by $11.74 \pm 0.15 \mathrm{mg} /$ day for fish fed diet $B$, and least $(11.69 \pm 0.09 \mathrm{mg} /$ day $)$ in fish fed diet $\mathrm{C}$ (Table 2).

Statistically, the weight gain, growth rate and specific growth rate varied significantly between the juvenile fish group fed the 3 diets at $p<0.05$, while the mean growth rate did not vary significantly between the juvenile fish group fed the 3 diets at $p>0.05$ (Table 2).

Table 1. Mean proximate composition of the experimental diets

\begin{tabular}{llll}
\hline Indices & Diet A (Control) (coppens) & Diet B (SBD) & Diet C (COBD) \\
\hline Crude Protein (\%) & $40.61 \pm 0.13^{\mathrm{a}}$ & $37.00 \pm 0.32^{\mathrm{b}}$ & $38.15 \pm 0.16^{\mathrm{c}}$ \\
Ether Extract (\%) & $11.71 \pm 0.10^{\mathrm{a}}$ & $6.70 \pm 0.12^{\mathrm{b}}$ & $10.00 \pm 0.30^{\mathrm{c}}$ \\
Crude Fibre (\%) & $7.43 \pm 0.01^{\mathrm{a}}$ & $5.13 \pm 0.13^{\mathrm{b}}$ & $4.30 \pm 0.33^{\mathrm{c}}$ \\
Ash (\%) & $9.10 \pm 0.12^{\mathrm{a}}$ & $6.67 \pm 0.33^{\mathrm{b}}$ & $5.00 \pm 0.00^{\mathrm{c}}$ \\
Moisture (\%) & $8.50 \pm 0.21^{\mathrm{a}}$ & $17.37 \pm 0.3^{\mathrm{b}}$ & $14.84 \pm 0.14^{\mathrm{c}}$ \\
NFE (\%) & $22.68 \pm 0.13^{\mathrm{a}}$ & $27.13 \pm 0.23^{\mathrm{b}}$ & $27.76 \pm 0.56^{\mathrm{c}}$ \\
\hline \multicolumn{4}{c}{ NFE = Nitrogen Free Extract } \\
\multicolumn{4}{c}{ Values are in mean \pm standard deviation } \\
\\
${ }^{SBD}=$ Shrimp-based diet, \\
\\
Values with different superscript are significantly different at p<0.05
\end{tabular}

Table 2. Mean growth performance indices of $C$. gariepinus fed experimental diets

\begin{tabular}{|c|c|c|c|}
\hline Growth indices & Diet A (Control) (coppens) & Diet B (SBD) & Diet C (COBD) \\
\hline Initial Weight (g) & $800.00 \pm 0.00$ & $800.00 \pm 0.00$ & $800.00 \pm 0.00$ \\
\hline Final Weight (g) & $17989.33 \pm 506.61^{\mathrm{a}}$ & $15845.33 \pm 202.42^{b}$ & $15157.33 \pm 108.25^{\mathrm{c}}$ \\
\hline Weight Gain (g) & $17189.33 \pm 506.61^{a}$ & $15045.33 \pm 202.42^{b}$ & $14357.33 \pm 108.25^{\mathrm{C}}$ \\
\hline Initial Length (cm) & $9.07 \pm 0.34$ & $9.11 \pm 0.17$ & $9.28 \pm 0.27$ \\
\hline Final Length (cm) & $40.85 \pm 0.39^{a}$ & $39.76 \pm 0.10^{b}$ & $38.69 \pm 0.35^{\mathrm{c}}$ \\
\hline Length gain $(\mathrm{cm})$ & $31.78 \pm 0.22^{\mathrm{a}}$ & $30.64 \pm 0.21^{a}$ & $29.42 \pm 0.25^{\mathrm{a}}$ \\
\hline Growth Rate & $111.62 \pm 3.29^{a}$ & $97.69 \pm 1.31^{\mathrm{b}}$ & $93.23 \pm 0.70^{\mathrm{C}}$ \\
\hline SGR (\%/day) & $2.02 \pm 0.02^{\mathrm{a}}$ & $1.94 \pm 0.01^{b}$ & $1.91 \pm 0.01^{\mathrm{c}}$ \\
\hline MGR (mg/day) & $11.88 \pm 0.29^{\mathrm{a}}$ & $11.74 \pm 0.15^{\mathrm{a}}$ & $11.69 \pm 0.09^{a}$ \\
\hline
\end{tabular}




\subsection{Food Utilisation of Fish Fed Experimental Diets}

The summary of the food utilisation indices of $C$. gariepinus juveniles fed 3 diets is shown in Table 3 . Fish fed Coppens feed consumed more food (41650.00 $\pm 315.34 \mathrm{~g})$, followed by fish fed diet B with $39034.24 \pm 86.34 \mathrm{~g}$ and least in fish fed diet $C$ with $38276.00 \pm 432.97 \mathrm{~g}$. Juveniles fed Coppens feed did better, with a conversion ratio (2.42 \pm 0.06$)$, followed by $2.59 \pm 0.04$ for fish fed diet $B$ and $2.67 \pm 0.03$ for fish fed diet C. Food conversion efficiency was greater in juveniles fed diet A (41.26 $\pm 0.94 \%)$, followed by $38.54 \pm 0.54$ $\%$ for fish fed diet B and least (37.52 $\pm 0.51 \%$ ) in fish fed diet $\mathrm{C}$ (Table 3).

The food consumed and food conversion ratio varied significantly between the fish fed the 3 diets at $p<0.05$, while food conversion efficiency was not significantly different between the 3 treatment groups at $p>0.05$ (Table 3).

\subsection{Physico-chemical Parameters Culture Water}

The summary of the mean physico-chemical parameters of culture water in tank with fish fed 3 diets is shown in table 4. For the fish group fed coppens (Diet $A$ ), the temperature of the water ranged from $27.27-32.83{ }^{\circ} \mathrm{C}$, with a mean and standard deviation of $29.975 \pm 0.291{ }^{\circ} \mathrm{C}$, while $\mathrm{pH}$ ranged from $6.87-7.40$, with a mean and standard deviation of $7.082 \pm 0.144$. The dissolved oxygen (DO) ranged from 3.33 - 5.33 $\mathrm{mg} / \mathrm{L}$, with a mean and standard deviation of $4.648 \pm 0.603 \mathrm{mg} / \mathrm{L}$, while the ammonia level ranged from $0.00-0.17 \mathrm{mg} / \mathrm{L}$, with a mean and standard deviation of $0.133 \pm 0.048 \mathrm{mg} / \mathrm{L}$ (Table 4).

For the fish group fed shrimp based diet (SBD) (Diet $\mathrm{B}$ ), the temperature of the water ranged from $27.33-33.46^{\circ} \mathrm{C}$, with a mean and standard deviation of $30.099 \pm 0.380{ }^{\circ} \mathrm{C}$, while $\mathrm{pH}$ ranged from 6.91 - 7.19, with a mean and standard deviation of $7.085 \pm 0.088$. The dissolved oxygen (DO) ranged from $3.37-5.34 \mathrm{mg} / \mathrm{L}$, with a mean and standard deviation of $4.188 \pm 1.370 \mathrm{mg} / \mathrm{L}$, while the ammonia level ranged from $0.00-0.20$ $\mathrm{mg} / \mathrm{L}$, with a mean and standard deviation of $0.130 \pm 0.052 \mathrm{mg} / \mathrm{L}$ (Table 4).

For fish fed Diet C, the temperature of the water ranged from $27.30-33.10{ }^{\circ} \mathrm{C}$, with a mean and standard deviation of $30.111 \pm 0.278{ }^{\circ} \mathrm{C}$, while $\mathrm{pH}$ ranged from $6.93-7.27$, with a mean and standard deviation of $7.089 \pm 0.119$. The dissolved oxygen (DO) ranged from 3.76 - 5.34 $\mathrm{mg} / \mathrm{L}$, with a mean and standard deviation of $4.574 \pm 0.559 \mathrm{mg} / \mathrm{L}$, while the ammonia level ranged from $0.00-0.17 \mathrm{mg} / \mathrm{L}$, with a mean and standard deviation of $0.126 \pm 0.045 \mathrm{mg} / \mathrm{L}$ (Table 4).

The water temperature, $\mathrm{pH}, \mathrm{DO}$ and ammonia level of culture water with fish fed the 3 diets were all within the range suitable for a healthy living of fish. Statistically, the temperature, $\mathrm{pH}$, DO and ammonia levels varied significantly between the culture water with fish fed the 3 diets at $p<0.05$ (Table 4).

\section{DISCUSSION}

The primary objectives of the aquaculture industry are to optimize growth and make available high-quality fish [2]. The increase in the World-wide awareness of fish as a treasured source of protein, has led to an increase in the prospects of aqua feeds with diets being specially design to meet the nutritional needs of species, life cycle and the health conditions of fish [3]. Fishmeal has been the most used source of protein incorporated in culture fish diets, despite the fact that, fish supply is not increasing globally [4]. In fish farming, feed and its application still remain a limiting constraint to fish

Table 3. Mean food utilization indices of $C$. gariepinus fed experimental diets

\begin{tabular}{llll}
\hline Growth Indices & Diet A (Control) (coppens) & Diet B (SBD) & Diet C (COBD) \\
\hline Weight Gain (g) & $17189.33 \pm 506.61^{\mathrm{a}}$ & $15045.33 \pm 202.42^{\mathrm{b}}$ & $14357.33 \pm 108.25^{\mathrm{C}}$ \\
Food Consumed (g) & $41650.00 \pm 315.34^{\mathrm{a}}$ & $39034.24 \pm 86.34^{\mathrm{b}}$ & $38276.00 \pm 432.97^{\mathrm{C}}$ \\
FCR & $2.42 \pm 0.06^{\mathrm{a}}$ & $2.59 \pm 0.04^{\mathrm{b}}$ & $2.67 \pm 0.03^{\mathrm{c}}$ \\
FCE (\%) & $41.26 \pm 0.94^{\mathrm{a}}$ & $38.54 \pm 0.54^{\mathrm{a}}$ & $37.52 \pm 0.51^{\mathrm{a}}$ \\
\hline \multicolumn{4}{c}{ SBD $=$ Shrimp-based diet, COBD = Chicken Offal-based diet } \\
FCR= Food conversion ratio, \\
FCE = Food conversion efficiency \\
Values are in mean \pm standard deviation \\
Values with different superscript are significantly different at $p<0.05$
\end{tabular}


Table 4. Mean physico-chemical parameters of water in each treatment tank

\begin{tabular}{|c|c|c|c|c|}
\hline Water parameters & Tank A (control) & Tank B (SDB) & Tank C (COBD) & FAO limit \\
\hline Temperature $\left({ }^{\circ} \mathrm{C}\right)$ & $\begin{array}{l}29.975 \pm 0.291^{\mathrm{a}} \\
(27.27-32.83)\end{array}$ & $\begin{array}{l}30.099 \pm 0.380^{b} \\
(27.33-33.46)\end{array}$ & $\begin{array}{l}30.111 \pm 0.287^{c} \\
(27.30-33.10)\end{array}$ & $<40$ \\
\hline $\mathrm{pH}$ & $\begin{array}{l}7.082 \pm 0.144^{\mathrm{a}} \\
(6.87-7.40)\end{array}$ & $\begin{array}{l}7.085 \pm 0.088^{b} \\
(6.91-7.19)\end{array}$ & $\begin{array}{l}7.089 \pm 0.119^{c} \\
(6.93-7.27)\end{array}$ & $6-9$ \\
\hline $\begin{array}{l}\text { Dissolved oxygen } \\
(\mathrm{mg} / \mathrm{L})\end{array}$ & $\begin{array}{l}4.648 \pm 0.603^{a} \\
(3.33-5.33)\end{array}$ & $\begin{array}{l}4.188 \pm 1.370^{b} \\
(3.37-5.34)\end{array}$ & $\begin{array}{l}4.574 \pm 0.559^{c} \\
(3.76-5.34)\end{array}$ & $>4$ \\
\hline $\begin{array}{l}\text { Ammonia }\left(\mathrm{NH}_{3}\right) \\
(\mathrm{mg} / \mathrm{L})\end{array}$ & $\begin{array}{l}0.133 \pm 0.048^{a} \\
(0.00-0.17)\end{array}$ & $\begin{array}{l}0.130 \pm 0.052^{b} \\
(0.00-0.20)\end{array}$ & $\begin{array}{l}0.126 \pm 0.045^{c} \\
(0.00-0.17)\end{array}$ & $<1$ \\
\hline
\end{tabular}

farmers because of unavailability and high cost of protein sources, resulting in inadequate feeding rates and frequencies. This study was driven towards developing feeds using locally available ingredients and some common waste products such as chicken offals and shrimpwaste within the Calabar environments as protein sources, while trying to compare it with Coppens feed which over time has been proven to be of good quality, giving a better yield in terms of growth.

The nutritional composition of the 3 feeds used differed in this study, with coppens being the best from the nutritional point of view, but all 3 feeds were well formulated to have a balanced diet. The differences in the nutritional levels of the 3 diets could be due to the difference in the components of the 3 diets. This corroborated with the findings of [20] and [21], who both purported that, the nutritional constituents of fish meal can vary depending on the part being processed.

The indices of growth examined in this study revealed that weight gain, growth rate (GR) and specific growth rate (SGR) varied between diets. Findings observed is in line with [25] who stated in their report that feed standard is a matter of how efficient an animal's nutrient requirement is met by that feed. Growth response for fish observed in this study for a period of 22 weeks is an indicator of the completeness of the three experimental diets in terms of nutrient required by fish as reflected in the proximate levels of the three experimental feed. Implication of these findings reflects that, fish fed Coppens feed grew faster than fish fed shrimp based diet (SBD), while fish fed chicken offal based diet (COBD) had the slowest growth. This can be attributed to the components which gives an odour of fish to Coppens feed and its floatable nature. This finding agrees with the findings of $[26,27]$, who in their report stated that business feeds like Coppens, Vital, Multifed, and Euro, release a stronger odour that is fishy in nature. Going by Coppens manufacturer's label, the constituent macronutrients differed from ingredients used in formulating shrimp based diet (SBD) and chicken offal based diet (COBD), although some ingredients and additives were almost the same. [26], also reported that $C$. gariepinus like most catfish feed mostly using olfactory senses. This could be responsible for coppens feed being more inviting than diet $\mathrm{B}$ and $\mathrm{C}$. However the 3 feeds were consumed by the fish, albeit at different rate.

The importance of the amount of feed consumed cannot be over emphasized, because of its vitality for checking the ratio of food conversion (FCR) and food conversion efficiency (FCE). Since feed are costly, FCR or FCE are important factors for the accurate use of feed [28]. Research has consistently highlighted that good knowledge of FCR helps the farmer to satisfactorily feed the fish $[29,30,31,32,33,34$, 27]. In this study, Diet $A$ were more readily converted by fish as indicated by the high FCR and FCE, followed by Diet B and then Diet $C$ as the least. The high conversion of coppens could be due to it having a strong fish odour, as well as being more nutritionally balanced than the other diets.

The water quality parameters varied between treatment tanks, although all water quality parameters monitored were normal and at a tolerable limits for the rearing of $C$. gariepinus. 


\section{CONCLUSION}

In connection with these findings, it was concluded that shrimp based diet (SBD) and chicken offal based diet (COBD) competed positively with coppens regarding nutritional composition, growth performance and feed utilisation of $C$. gariepinus. Despite the fact that coppens yielded better nutritional composition, fish growth performance and feed utilisation, fish fed SBD and COBD to maturity can be used as a reliable broodstock. In conclusion, the use of coppens feed for catfish farming is advocated, but for a more cost effective system, a formulated diet using shrimp or chicken offal as the animal protein source is recommended to fish farmers in Nigeria. More researches should be carried out on using chicken offals and shrimp based diets in fish feed formulation.

\section{ETHICAL CONSIDERATION}

The authors ensured that all ethical and other basic principles underlying behavior and advancing welfare for the use of animals in research, including handling, relevant laws and regulations were considered before proceeding with the research. Permission was also received from the relevant bodies for the use of fish for this experiment.

\section{COMPETING INTERESTS}

Authors have declared that no competing interests exist.

\section{REFERENCES}

1. Dada AA and Wonah C. Production of exotic Clarias gariepinus at varying stock density in outdoor pond. Journal of Aquatic Science. 2003;18(1):21-24.

2. Bello OS, Olaifa FE, Emikpe $B O$ and Ogunbanwo ST. The effect of walnut (Tetracarpidium conophorum) leaf and onion (Allium cepa) bulb residues on the tissue bacteriological changes of Clarias gariepinus juveniles. Bulletin of Animal Health and Production in Africa. 2012;60(2):205-212.

3. Rawling MD, Merrifield DL, Snellgrove DL, Kühlwein $H$, Adams $A$ and Davies SJ. Haemato-immunological and growth response of mirror carp (Cyprinus carpio) fed a tropical earthworm meal in experimental diets. Fish and Shellfish Immunology. 2012;32:1002-1007.
4. Barlow S. Fish meal-supply limits demand. Feed Technology. 1997;1(1):34-35.

5. Quatararo N, Bell JD, Allan GL. Replacement of fishmeal in diets for Australian snapper, (Pagrus auratus). Aquaculture. 1998a;166:279-295.

6. Quatararo N, Bell JD, Alla GL. Subtitution of fishmeal in diets for the carnivorous marine fish, Pagrus auratus (Bloch and Scheider) from Southeastern Australia. Asian Fisheries Society. 1998b;10:269279.

7. Ruchimat T, Masumoto $\mathrm{T}$ and Hosokawa $H$. Nutritional evaluation of several protein sources of yellowtail. Bulletin of Marine Sciences and Fisheries, (Kochi University). 1997;17:69-78.

8. Usman R, Samuel L, Kamaruddin U, Tauki A. Replacement of fishmeal with poultry offal meal in diets for humpback grouper (Cromileptes altivelis) grow-out. Indonesian Aquaculture Journal. 2006;1: 45-52.

9. Sogbesan OA, Ugwumba AA. Bionomics evaluation of garden snail (Limicolaria aurora Jay) meal in the diet of Clarias gariepinus (Burchell) fingerlings. Nigeria Journal of Fisheries. 2006;2(3):358-371.

10. Sogbesan AO, Ugwumba AA, Etundayo TM. Performance of Heterobranchus longifilis fingerlings fed maggot mealbased diets in miniflow through systems. Fisheries Society of Nigeria Conference Proceedings. 2006;216.

11. Faturoti EO. Beneath the Ripples and Sustainable fish Production. Inaugural Lecture, University of Ibadan, Ibadan. 2000;54.

12. Moreki JC, Tiroesele B, Chiripasis C. Prospects of utilizing insects as alternative sources of protein in poultry diets in Botswana: A review. Journal of Animal Science. 2012;2(8):649-658.

13. Abowei JF and Ekubo EN. A review of conventional and unconventional feeds in Fish Nutrition. British Journal of Pharmacology and Toxicology. 2011;2(4): 179-191.

14. AAFCO. Chicken-by-product meal. Champaign, USA. Association of American Feed Control Officials. 12th Edition. 2010;125.

15. Alceste CC, Jory DE. Tilapia alternative protein sources in Tilapia feed formulation. Aquaculture Magazine. 2000;26(4):3-4. 
16. FAO. Review of the state of the World Fishery Resources. Circular No. 942FIRF/C942, Rev. 2 (En). 2009;110.

17. Udo UI, Ndome CB, Ekanem SB, Asuquo $P E$. Use of stochastic programming in least-cost-feed formulation for African catfish (Clarias gariepinus) in semi intensive culture system in Nigeria. Journal of Fishieries and Aquaculture Science. 2011;6:447-455.

18. Glencross BD, Booth M, Allan GL. A feed is only as good as aquaculture feeds. Aquaculture Nutrition. 2007;13:17-34.

19. Olele NF. Growth response of Heteroclarias fingerlings fed on earthworm meal in hatchery tanks. Journal of Life Science. 2011;3(2):131-136.

20. Dale N, Fancher B, Zumbado M, Villacres A. Metabolizable energy content of poultry offal meal. Journal of Applied Poultry Resources. 1993;2:40-42.

21. Watson H. Poultry meal vs poultry-byproduct meal. Dogs in Canada Magazine. 2006;2:9-13.

22. FAO. Fisheries statistics. http://www.fao.org Accessed 1st October 2012. 2003: 87.

23. Small BC. Accounting for water temperature during hydrogen peroxide treatment of Channel Catfish eggs. North American Journal of Aquaculture. 2004;66: 162-164.

24. AOAC. Official methods of analysis of the association of official analytical chemists, 17th. edn., Gaithersburg, MD. USA, AOAC International. 2000;168.

25. De Silva SS, Anderson TA. Fish nutrition in aquaculture. London, Ghapman and Hall. $1995 ; 319$.

26. Agbokei EO, Oparah CA, Apapa U. Growth of Clarias gariepinus juveniles fed five commercial feed. Continental Journal of Fisheries and Aquatic Sciences. 2011;5(3): 1-5.

27. Ekanem AP, Eyo VO, Austin IO, Udeme IE, Paul JU. A comparative study of the growth performance and food utilisation of the African catfish (Clarias gariepinus) Fed Unical Aqua Feed and Coppens Commercial Feed. Journal of Marine Biology and Oceanography. 2012;1:2-7.

28. Eyo VO, Ekanem AP. Effect of feeding frequency on the growth, food utilization and survival of African catfish (Clarias gariepinus) using locally formulated diet. African Journal of Environmental Pollution and Health. 2011;9(2):11-17.

29. Shabbir S, Salim M, Rashid M. Study on the feed conversion ratio (FCR) in major carp Cirrhinus mrigala fed on sunflower meal, wheat bran and maize gluten $30 \%$. Pakistan Veterinary Journal. 2003;23(1):13.

30. Jabeen S, Salim M, Akhtar P. Study on feed conversion ratio of major carp Cirrhinus mrigala fingerlings fed on cotton seed meal, fishmeal and barley. Journal of Parkistan Veterinary. 2004;24(1):42-46.

31. Ali T, Salim M. Studies on the growth response and feed conversion (FCR) of Labeo rohita fingerlings fed on rice polish, fishmeal and sunflower meal. International Journal of Agriculture and Biology. 2004;6(5):914-917.

32. Saeed M, Salim M, Noreen U. Study of the growth performance and feed conversion ratio (FCR) of labeo rohita fed on soya bean meal, blood meal and corn gluten $60 \%$. Pakistan Veterinary Journal. 2005; 25(3):121-126.

33. Inayat L, Salim M. Feed conversion ratio of major Carp, Cirrhinus mrigala, fingerlings fed on soyabean meal, maize gluten and maize. Journal of Pakistan Veterinary. 2005;25(1):13-17.

34. Gull Y, Salim M, Shahzad K, Noreen U. Study on the growth performance and feed conversion ratio of labeo rohita fed on soyabeans meal, bloodmeal and corn gluten $60 \%$. Industrial Journal of Biological Sciences. 2005;24:556-562.

(c) 2018 Ayim et al.; This is an Open Access article distributed under the terms of the Creative Commons Attribution License (http://creativecommons.org/licenses/by/4.0), which permits unrestricted use, distribution, and reproduction in any medium, provided the original work is properly cited.

Peer-review history:

The peer review history for this paper can be accessed here: http://www.sdiarticle3.com/review-history/43149 